\title{
9. Drug substances introduced by the Macassans: The mystery of the tobacco pipe
}

\author{
Maggie Brady
}

\section{The real first fleet}

It has become conventional wisdom to assert that the arrival of Captain Arthur Phillip's First Fleet in 1788 was the means by which both alcohol and tobacco were first introduced to Australia's Indigenous people. This was not the case, of course, for it was Australia's other 'first fleet', of Macassan praus, already established as an annual event well before Phillip's arrival (Burningham 1994), which brought these drug substances to a virgin population in the north. Until the first British attempts at settlement on that northern coast, ${ }^{1}$ the Macassans were the only regular source of alcohol and tobacco for the Aboriginal people who became users of these substances.

Aboriginal people formed regular and orderly trading relationships with these foreigners, who were no threat to their primary ownership of the land and sea, and who took a resource - trepang - for which Aborigines had no use. These relationships made it possible for significant numbers of Aboriginal men to travel to and live in Makassar, where they experienced the daily life of people from another society. Contact with the Macassans in Makassar itself and in Australia introduced Aboriginal people along the northern coastline to people of another religion, to a foreign language that many learned and spoke, and it exposed them to the customs, artefacts, food and drugs of another culture. The Yolngu of northeast Arnhem Land refer to these people as the 'batharripa'. The term derives from the Makassarese and Bugis word 'pataripang', meaning 'trepang fisherman' (Zorc 1986, p. 20).

Drug substances (alcohol, tobacco, betel nut and possibly opium) were brought on the voyages, perhaps initially for the use of the captains and crew. Once two drug items - alcohol and tobacco - were found to be particularly welcome, more supplies would have been brought as items of trade. There has long been debate about how influential the Macassans were and about how much alcohol

1 Fort Dundas on Melville Island (1824-28) was a disastrous failure, followed by two more failed settlements on the Cobourg Peninsula: Fort Wellington at Raffles Bay (1827-29) and Victoria at Port Essington (1838-49). 
and tobacco they might have brought. W. L. Warner, for example, famously downplayed their influence and Macknight (1976, p. 84) suggested there was no sign that vast quantities of food or other goods were made available to Aborigines, partly because of space restrictions on praus. Irrespective of the quantities involved, it was the prestige attached to these items that was important. For Aboriginal people these two drug substances were significant enough to be commemorated in song, ceremony and cosmology, in art and artefacts, and in handed-down stories and memories. Aboriginal people experimented with these substances, learned to smoke and drink, experienced inebriation, had fun, incorporated the material culture associated with them into their ceremonial and trading networks and borrowed words from another language to describe them (Brady 2008). 'Nganitji' (alcohol) and 'ngarali' (tobacco) - the Yolngu/ Makassarese language terms - are firmly part of the intercultural experience of the region today.

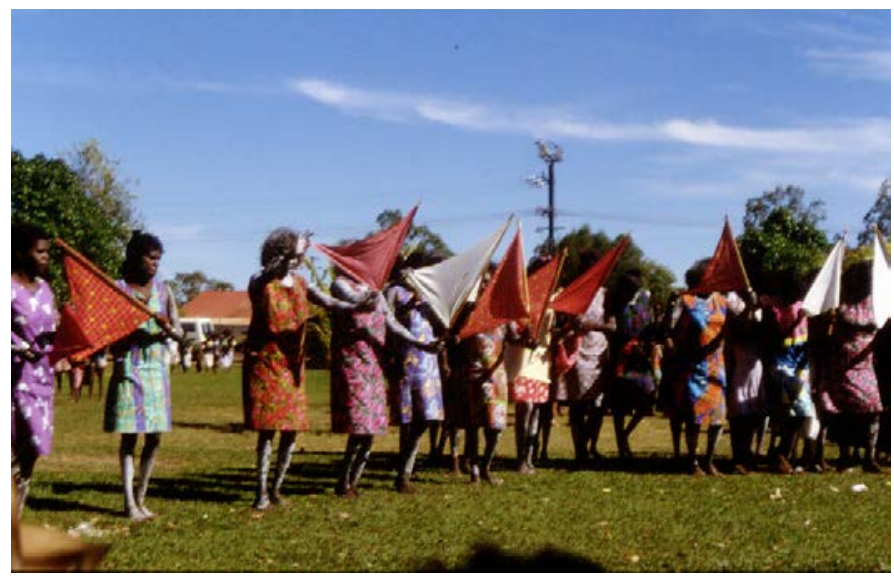

Figure 9.1 Numbulwar dancers perform the Macassan 'red flag' dance at Barunga Festival, 1988

Photo: M. Brady

\section{Arrack}

The alcoholic drinks brought by the Macassans appear to have been predominantly arrack; some brandy and Dutch 'square-face' gin bottles have been found in excavations of Macassan campsites, although what the bottles might have actually contained is not known. Gin is mentioned by some observers, but it is unclear whether these are references to the drink we know by that name or whether they use 'gin' as a convenient generalisation for a clear, distilled spirit that was, in fact, arrack. 
Arrack is a spirit that can be made from the fermented sugars and sugary sap of a large number of plants and trees, including dates, sugar cane, rice and several types of palm. Nearly every variety of palm produces a saccharine juice in various quantities (Brady and McGrath 2010). In the Indonesian archipelago, palms used for making these drinks include the lontar palm in Rote, Timor and Makassar (Borassus sundaicus Becc.), the fan or 'toddy' palm on Savu (Borassus flabillifer), and the nypa palm (Nypa fruticans) in a number of locations. Wallace noted large numbers of sugar-palms (Arenga saccharifera) growing around Makassar (Wallace 1989, p. 239; cf. Beaglehole 1963, p. 162; Earl 1882, p. 152; Fox 1977). The juice can be drunk fresh from the tree, having been collected as it drips from cuts made in the buds that are to produce flowers. At this stage it is nonalcoholic, or it can be consumed after a day or two when it becomes fizzy; a few more days and it becomes sour and fermented - this is what is now commonly known as 'toddy' or 'sour toddy', and contains alcohol. The Macassans called this drink 'sagueir', according to Alfred Wallace, who said that it took the place of beer. An 1885 drawing of a Macassan bamboo container for collecting palm juice reiterates the use of this term (Atlas 1885, plate 10, figs 34, 35; Wallace 1989 , p. 224). ${ }^{2}$ Distillation of this fermented liquid produces arrack.

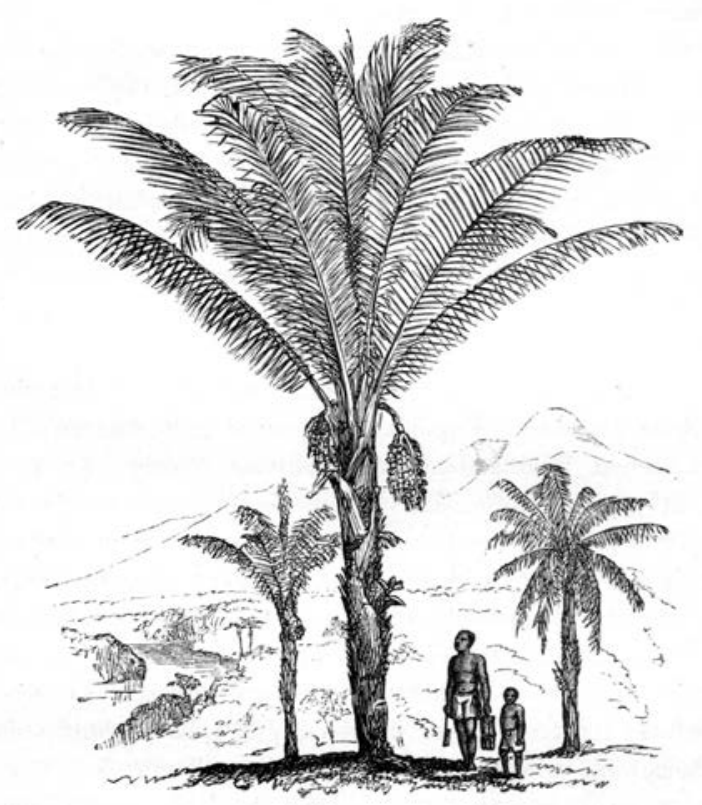

Figure 9.2 Sugar palm (Arenga saccharifera)

Source: Wallace (1989, p. 238)

2 The term 'ballo' is also used in Makassar for palm wine. 
In Batavia in 1770, arrack was cheaper than claret wine and had a high alcohol content (Wallace described it as being as strong as West Indian rum-that is, anything between 40 per cent and 70 per cent alcohol by volume). Sometimes referred to as 'Java rum', arrack was consumed widely and with great abandon across the archipelago. The locally distilled version was available for sale legally and illegally in Makassar (Knaap and Sutherland 2004, p. 93) and high-quality arrack was imported from Batavia to Makassar. The terms 'arrack', 'rak' and 'raki' derive from the Arabic 'araq' ('sweat', presumably a reference to the droplets of clear fluid made during distillation), and the drink has a long history in the Middle East as well as in northern parts of Africa, in India and Southeast Asia. Unlike the fermented toddies (often known as 'palm wine') also made in Southeast Asia and the Pacific (which became unpalatable over time), distilled arrack travelled well. Because of this it was frequently carried by maritime explorers, including James Cook on the Endeavour and the French expeditions led by Nicolas Baudin and Dumont d'Urville. Arrack was given to Aboriginal people in exchange for tortoise and pearl shell (Gillen 1968, p. 317), to pay for their labour and, according to Ronald and Catherine Berndt (1954, p. 47), for women.

\section{Betel nut}

Betel nut - probably the oldest indigenous psychoactive substance in Southeast Asia - was chewed by Macassans and was (and still is) commonly used throughout the archipelago (Rooney 1993). Strictly speaking, it is not the betel nut at all, but the nut or seed of the areca palm (Areca catechu) that is chewed, together with the leaf of the betel pepper (Piper betle) and lime; tobacco was added as flavouring. Tobacco could also be held in the mouth after the initial salivation produced by the betel chew, producing copious red, blood-like saliva (Reid 1985, p. 537). French and English observers in the nineteenth century such as Nicolas Baudin and P. P. King frequently expressed disgust at the practice, which was probably a response to the discolouration and blackening of users' teeth and the regular spitting out of red saliva (Hordern 2002, p. 117). Because of this, some early European visitors believed that many Asians had tuberculosis - they were thought to be spitting blood (Rooney 1993, p. 1).

Apart from the observations of betel-nut use in Southeast Asia made by contemporary travellers and maritime explorers (including Wallace, whose local assistant, Baderoon, was a chewer of betel), ${ }^{3}$ we know that the Macassan men who came to Australia were users of betel. In the 1890s, for example, Searcy noticed that boxes containing the 'necessary ingredients, etc., for making their

3 Baderoon had made several visits to northern Australia with the trepang fleets (Wallace 1989, p. 412). 
"quids" were lying around everywhere' (Searcy 1984, p. 26; cf. Mulvaney and Green 1992, p. 135). The archaeological record provides further evidence. An excavation at Anuru Bay (on the coast adjacent to South Goulburn Island) of the burial site of two Macassan men showed signs of betel use on their teeth (Macknight and Thorne 1968).

Despite the apparent pleasures and benefits of chewing betel nut, it seems that, like Europeans, Aboriginal people must have found the practice distasteful. They chose not to take up this drug use. According to Macknight (1976, p. 30), there is only one report of an Aboriginal person using betel, no available evidence of its adoption and no oral histories record its use. The areca palm occurs in north Queensland but there seems to be no record of Aboriginal people chewing the nuts there either (MacPherson 1921, p. 121). It is inconceivable that the Macassans would not have offered betel nut to their Aboriginal hosts, for in Southeast Asia betel functions as an avenue of communication that produces relaxed social interactions and as a marker of hospitality; its use is not restricted by the usual barriers of age, sex or class that are often invoked for other drug uses. It was also common practice to offer betel nut when greeting or farewelling visitors. Chewing betel nut is, however, an acquired taste and not immediately pleasurable: the first taste of betel is acrid and unpleasant. This may partly explain why Aboriginal people did not take to it. Nevertheless, an initial aversion to a drug is not the whole story (Courtwright 2001, p. 54); smoking tobacco is also usually thought disagreeable at first and yet the evidence shows that Aboriginal people rapidly took to this new way of ingesting nicotine.

\section{Tobacco}

The English, Dutch and Portuguese were responsible for the rapid spread of tobacco, which had arrived in Java around 1600 (Burkhill 1966, p. 1579). In the eighteenth century tobacco was a major import item into Makassar from China and Java (Knaap and Sutherland 2004, p. 94). In the 1850s Wallace saw tobacco growing on the lower slopes of the hills in Maros, $50 \mathrm{~km}$ from Makassar, and noted it was in high demand in Dobbo on Aru, along with other items carried on the large trading praus from Makassar, Ceram, Goram and Ke (Wallace 1989, pp. 239, 485).

Tobacco was one of the most popular items that Aboriginal people obtained from the Macassans (Macknight 1976, p. 30). Ronald and Catherine Berndt heard it called ' $j i$ ' (in its loose flake form), or 'batariba' (also the term used by the Yolngu for the Macassans themselves) (Berndt and Berndt 1954, p. 44). Others list 'dhambaku' (Mkr: tambáko) (Cooke 1987, p. 57; Zorc 1986). Thomson (1939, p. 90) notes that before the presence of Europeans, Arnhem Landers were entirely 
dependent for tobacco upon the Malay visitors, who brought with them 'large supplies' of coarse tobacco in twist form. ${ }^{4}$ This reliance manifests itself in a segment of the Macassan song cycle still performed today in northeast Arnhem Land: in the 'Tobacco Song', the dancers 'beg' and 'ask' (the Macassans) for tobacco. $^{5}$

\section{The 'Macassan' pipe}

The Macassans apparently also introduced the use and the manufacture of a distinctive, usually long, straight wooden pipe that has since been used for the smoking of tobacco by coastal Aboriginal people of Arnhem Land and the western Gulf of Carpentaria. Warner stated:

The Malays introduced both the use and manufacture of the tobacco pipe during the period in which they traded with the aborigines. Although the aborigines know that they acquired the pipe from the Malays, they believe they practiced smoking before this time...but nearly all the evidence seems to point to the introduction of smoking into Australia from a Malay source. (Warner 1958, p. 458)

Donald Thomson (1939, p. 87) wrote that the wooden pipes of Arnhem Land are...definitely of Indonesian origin and were probably introduced into Arnhem Land, with tobacco, by the early Macassar voyagers, or their predecessors'.

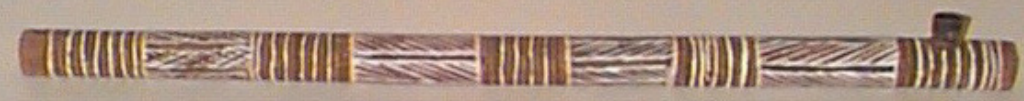

A $4 \longdiv { 7 } 6 \longdiv { 4 } 2$

\section{Figure 9.3 Decorated tobacco pipe, Arnhem Land}

Source: South Australian Museum, A47642

4 Macknight (1976, p. 116) provides cargo manifests for two praus, noting 1 picul of tobacco in 1883-84 and 0.75 piculs in $1902-02 ; 1$ picul $=60 \mathrm{~kg}$.

5 Dr Franca Tamisari, Personal communication. Loosely translated, the ngarali (tobacco) song includes the following: 'They saw them smoking ngarali. Smoking that ngarali. Djigirit [cigarette]. [The smoke goes] inside the head. They like it very much. They bin bought many tobacco in the city. Still smoking dhambaku. Smoke goes up and up, round and round, and turns into the sunset' (Eunice Djerrkngu Marika, Personal communication, 26 May 2005; cf. Cooke 1987, p. 17). 
Thomson (1949) documents pipes among other gerri ('goods') that were traded by coastal people with partners further south as part of the ceremonial exchange cycle, and he wrote the definitive ethnography of the pipe, describing Arnhem Land versions that ranged from about $20 \mathrm{~cm}$ to $90 \mathrm{~cm}$ in length (Thomson 1939). He detailed the quirky adaptations made by Aboriginal people to create the lining or bowl into which the tobacco goes: scrap tin, metal matchboxes, iron bands and hoops from driftwood; thimbles with their tops removed. The long wooden 'Macassan' pipes adopted by Aboriginal people were often decorated by their owners, not only as artistry but also as a way of claiming personal ownership of the pipe - and presumably the precious hoard of tobacco that went with it. Some pipes were incised or painted with totemic designs, transforming them into sacred items, the use of which could be restricted to initiated men, as Thomson perceptively noted. In a society in which generosity and sharing were pre-eminent values, this strategy enabled a man to conserve his tobacco and the means of smoking it, while being able to avoid any accusations of meanness (Thomson 1939, p. 89). Even today, the oral histories provided by Yolngu refer to the hoarding and protection of tobacco supplies during the Macassans' time:

They'd smash up the tobacco, squash it, and put it to keep in a bottle, a nganitji [alcohol] bottle; you could sleep with it: tobacco in bottle to keep it safe [mimes someone sleeping with their head resting on such a bottle]. Because ngarali, once they get the taste, they were addicted to that ngarali. You can't live without it. ${ }^{6}$

These pipes continued to be used in coastal Arnhem Land by Aboriginal men and women for smoking tobacco until the 1990s, although in recent years this has become less common. As has been the case elsewhere, cigarette smoking has taken over. 'Macassan-style tobacco pipes' are also sold as tourist art objects; museum curators and anthropologists interested in Macassan heritage and material culture are particularly drawn to some modern versions of these pipes, in which their makers have cleverly adapted soda siphon bulbs and empty shell casings to serve as the tobacco container.

\section{Confounding issues}

So the Macassans are the ones who have been universally credited with introducing the smoking of tobacco to Aboriginal people of the northern coastline, using these long pipes. The assumption has been that Aboriginal people observed the Macassans smoking the long pipes and replicated the pipes

6 Interview with Banampi Wunungmurra at Yirrkala, NT, 16 August 2005. 
and the behaviour. Nevertheless, this apparently straightforward example of the diffusion of drug use and drug paraphernalia from one people to another has some puzzling inconsistencies in this instance.

The first problem with this proposition is it appears that the people of Sulawesi, including the people we refer to as the Macassans, did not commonly smoke tobacco in pipes - in fact, they hardly smoked at all. Several commentators note that in Sulawesi and in the Indonesian archipelago as a whole, using pipes to smoke tobacco was the exception, rather than the rule. Smoking itself was not that common because the people of the region were betel-chewers, and betelchewers tend not to smoke tobacco, they use it in another way. Reid (1985, p. 537) states unequivocally: 'By the time of the British interregnum in the Indies (1811-1816), the primary use of tobacco in the [Indonesian] Archipelago was undoubtedly as a wad to cram between lip and gum after the initial salivation produced by the betel chew.'

Others agree that by the end of the eighteenth century the most popular way of consuming tobacco among ordinary Indonesians was to chew it with or without betel nut (Achadi et al. 2005; MacPherson 1921, p. 113; Goodman 1993, p. 89; Wallace 1989, p. 485). ${ }^{7}$ Earlier in the eighteenth century people did smoke to some extent: the elite in Java used fashionable, long European-style pipes, and even before this, in the mid seventeenth century, an indigenous form of cigarette appeared, wrapped in dried maize or banana leaf (Knaap and Sutherland 2004, p. 94; Reid 1985, p. 536). ${ }^{8}$ But according to Reid (1985, pp. 536-7), the practice of tobacco smoking had been generally discontinued among the islanders of the Indonesian archipelago by 1820. It was only in the twentieth century, after the Macassan trepang voyages had ended, that tobacco smoking - using cigarettes, not pipes - became widespread, as younger, 'modern' people from Sulawesi abandoned the chewing of betel (Strickland 2002, p. 86).

The second puzzling element to consider is the scant documentary or visual evidence of Macassans themselves smoking tobacco using these pipes. In rock art depictions of Macassans and praus, I know of only one showing a Macassan smoking what appears to be a long pipe. ${ }^{9}$ Most rock art, bark paintings and works on paper seem to portray the use of clay (European) pipes. Several of

\footnotetext{
7 Musing in 1921 on how Torres Strait Islanders learned how to smoke, MacPherson (a physician) believed it could not have been from the Malay nations 'since these people, even if they had ever reached thus far, rarely or never smoked tobacco, but only chewed it with their betel' (MacPherson 1921, p. 113).

8 This hand-rolled cigarette was introduced to coastal Aboriginal people either by the Macassans or by the 'Bayini', who were said to precede them. In the 1890s, Searcy (1984, p. 27) observed Aboriginal people 'lolling about' smoking cigarettes of Malay tobacco, rolled up in pandanus palm leaf. Warner's informants asserted they previously smoked native tobacco rolled in paperbark (Warner 1958, p. 461). The term for cigarette in several non-Yolngu languages derives from the Bugis and Makassarese 'galuru' ('to roll up') (Evans 1992, p. 74; Walker and Zorc 1981, p. 120), strongly suggesting a Macassan origin.

9 Thanks to Paul Taçon for this information. He photographed the site in the Mann River region (his ref. A1001).
} 
the Aboriginal crayon drawings collected in 1947 by Ronald Berndt at Yirrkala show goods brought by the Macassans (cf. Berndt and Berndt 1954). Two in particular ${ }^{10}$ are detailed illustrations showing trepang pots, stirrers, axes, glass bottles, knives, 'keris' (ceremonial daggers), rifles, frying pans, fireworks, coloured plates, tobacco (or betel) boxes and rice pots among other items. But there are no long 'Macassan' pipes among this trove of objects, nor are there drawings of Macassans with the long pipes.

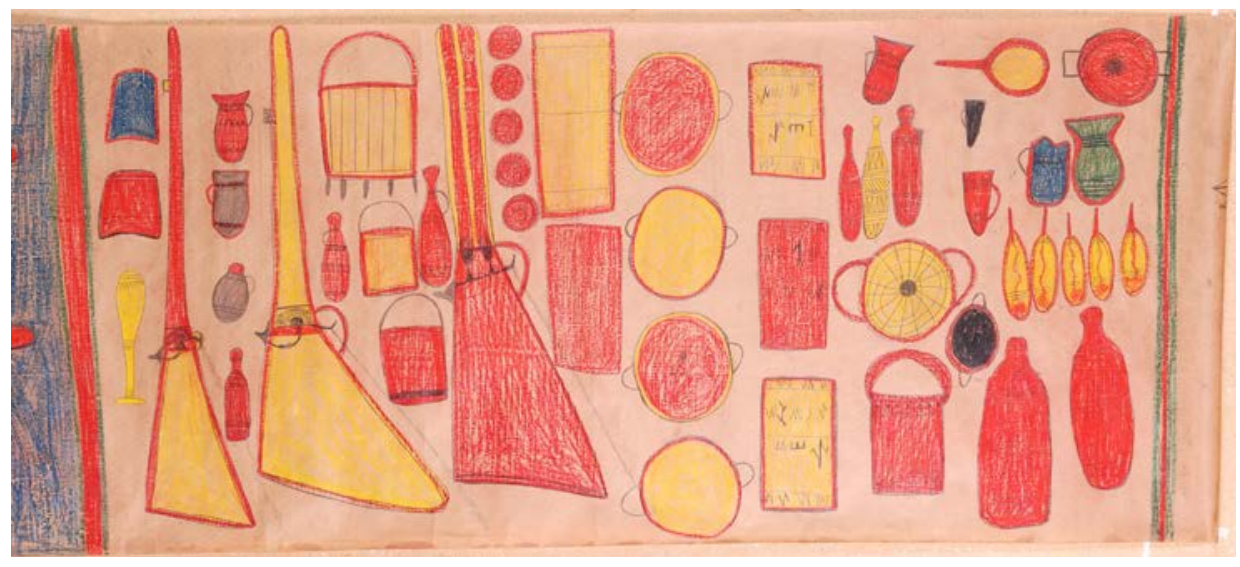

Figure 9.4 Goods introduced by the Macassans (crayon drawing on brown paper by Mawulan, 1947)

Source: Berndt Museum of Anthropology, WU7246

Clay pipes were undoubtedly more numerous. When maritime visitors and others encountered Aboriginal people during the Macassan years, they often found them using old clay pipes, and were besieged by requests for more of them. People such as Alfred Searcy were happy to oblige. The urgency of these demands implies that there were no other pipes available. ${ }^{11}$ Macknight (1976, p. 82) noted that fragments of clay pipes have been found in Macassan contexts and that clay pipes were 'probably' brought on the praus; however, they seem to date from the nineteenth century and, as Aborigines were given vast numbers of clay pipes, it is impossible to be certain they are imports from Makassar.

Finally, there is strong evidence that the long pipes used by Aboriginal people to ingest tobacco were originally opium pipes (Cawte 1985; Macknight 1976). The only difference between the opium pipes used in Makassar and elsewhere, and the pipes made by Aboriginal people for tobacco, is that the Aboriginal version of the pipe has a hole near the distal end lined with tin, or some other

10 Drawings numbering WU7246 and WU7163, Berndt Museum of Anthropology, Perth.

11 In the 1860s Webling (1995, pp. 67-8) reported seeing a Dutch-made pipe at an Aboriginal campsite near Croker Island. 
material, making an open cylindrical container into which the tobacco can be tamped. An opium pipe has a covered, round metal bowl at this spot in which the ball of opium is heated.

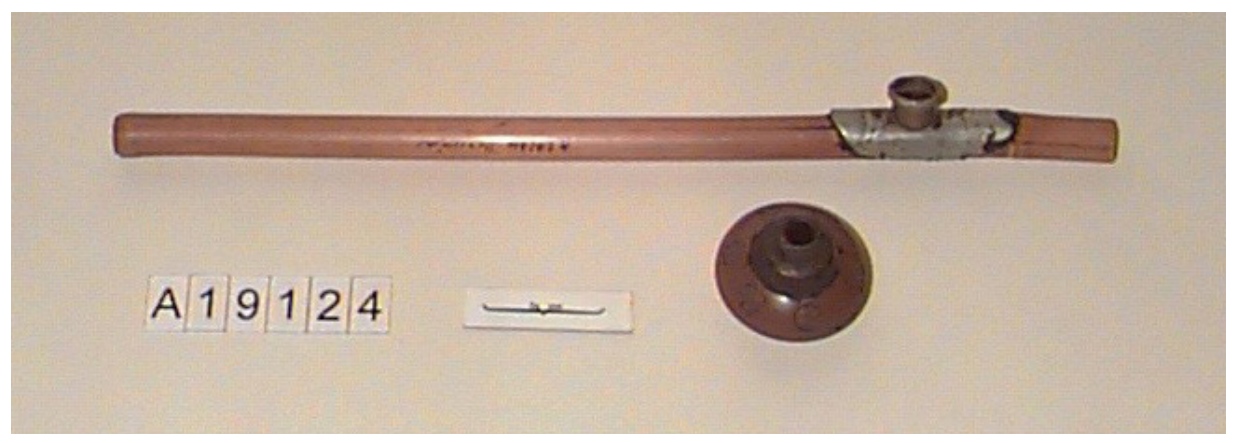

Figure 9.5 Opium pipe and bowl made in China. Collected by Police Inspector Waters, Darwin, 1890

Source: South Australian Museum, A19124

Opium was widely used in Makassar and the surrounding region during the eighteenth and nineteenth centuries (Wallace 1989, p. 381). It was said to help digestion, to strengthen the stomach and, perhaps something of an understatement, to produce charming dreams. A contemporary account of the habits of the people of the kingdom of Macassar held that opium was the 'most admired' of all their 'simples' (Gervaise 1971). ${ }^{12}$ When Dumont D'Urville and the Astrolabe visited Makassar in May 1839, the French observed that the local population were reckless gamblers and addicted to opium smoking; this did not, however, prevent some of the Astrolabe's officers from trying it (Rosenman 1992 , p. 181). In 1885 the opium pipe was thought common enough to warrant its inclusion alongside depictions of everyday Macassan household objects and artefacts (Atlas 1885, plate 10). Gervaise (1971) commented on the apparent contradiction inherent in such drug-taking among a people who had converted to Islam, suggesting that using opium had a strategic advantage: it gratified users with the pleasures of intoxication, while adhering to the prohibition on drinking wine (cf. Courtwright 2001 p. 33). In a similar vein, during the Endeavour's 1770 visit to the region, Joseph Banks opined that Islamic restrictions on the use of strong liquors had driven the Indonesians from liquid to solid intoxicators such as opium and tobacco (Beaglehole 1963, p. 214). ${ }^{13}$

12 'Simples' is probably used here in the sense of a medicine or medicament with only one constituent, such as a herb or plant (Oxford Shorter English Dictionary)

13 Wallace (1989, p. 224) observed that the Macassans were 'nominal Mohammedans' and lax in their religious observances. 
There is strong linguistic evidence from Aboriginal Australia to support the proposition that the Macassan pipe was originally an opium pipe. In their studies of Makasar or Makassarese loan words, linguists have documented numerous terms that associated the pipes with opium. In the Yolngu language a widespread term for pipe, 'bamutuka', derives from the Makassarese 'pammudukan', meaning 'bamboo opium pipe'. Other loan words used in the region include 'ma:ta' (long wooden pipe), which derives from the Bugis or Makassarese 'mada' for 'prepared opium' (Zorc 1986). Yet another word used for pipe, 'jandu', is borrowed from the Bugis, Makassarese, Javanese and/or Malay 'candu', meaning 'prepared opium, softened with water before use' (Walker and Zorc 1981, pp. 118, 126; cf. Evans 1992). In order for these introduced words to become embedded in Aboriginal languages, they, and the objects they describe, must have been in frequent use by the Macassans.

So, should we assume that the pipes and/or the opium itself travelled to Australia with the trepang fishers? And do we therefore assume that there were opium-smokers among the crews? We know that opium entered Makassar, was available and was commonly in use there. We also know that Macassan captains in Australian waters were interested in opium. When praus arrived at the British settlement of Raffles Bay for the trepang season of 1829, for example, some captains approached the British wanting items to take back with them such as scissors, razors, saws and muskets, and they were particularly interested in whether the British had any opium (Mulvaney and Green 1992, p. 139). Macknight thought it unlikely that much, if any, opium ever came on the praus (1976, p. 118). The Berndts thought it 'possible' (Berndt and Berndt 1954, p. 44), and provided a term for it used by Aboriginal people: ' $j i$ ' (the same term for tobacco). It would surely have been problematic to have had opium addicts among the trepang crews: they were expected to engage in hard labour in a relatively limited time in order to maximise the profits from trepang sales. It would also have been virtually impossible to smoke opium in the time-honoured way in the crowded and unstable conditions onboard. Opium is most efficiently smoked in a reclining position, so that with concentration and a steady hand, the opium ball in its metal container can be 'cooked' over a heat source, usually an open flame (Zheng 2003). An open flame itself would be a fire risk onboard any sailing ship. ${ }^{14}$ Nevertheless, if the trepang crews did include opium users then these men would have brought with them their opium-smoking 'layout' including the pipes. This would explain the arrival of the pipes in Australia, but not their use for tobacco.

It is likely that Aboriginal people witnessed opium smoking in Makassar itself. Hundreds of Aboriginal men undertook what Searcy referred to as the grand

14 Smoking onboard Portuguese and Dutch ships was forbidden because of the risk of fire (Reid 1985, p. 537). 
tour' to Makassar with the praus, lived there and returning the following year (Searcy 1984, p. 86). In 1828-29, around 100 Aboriginal men were said to be in Makassar (Mulvaney and Green 1992, p. 140; Mulvaney 1988). MacGillivray at Port Essington wrote in 1845 that Aborigines 'frequently' accompanied the Macassans (Cameron 1999, p. 147). Yolngu informants said some Yolngu people had lived in Makassar for many years, married and had children there (Djalatjirri in Cooke 1987, p. 46). Not only could Aboriginal men have observed opium smoking, they also would have had the opportunity to obtain opium pipes themselves. But perhaps of greater significance for this discussion about the transformation of the opium pipe into a tobacco pipe is an observation made in Makassar early in the eighteenth century. In an account published in 1701, the French naturalist and explorer Nicolas Gervaise provided a description from Makassar of people smoking tobacco with opium, with the tobacco as a flavouring or enhancer of the drug:

Tis dangerous therefore to contract a habit of smoaking tobacco thus sprinkl'd with this tincture of Ophyon; for in a short time it will become so necessary, that there will be no living without it. Seeing that they who leave it off, presently grow lean, languish, and soon after die of a consumption. But it is much more dangerous to use it to excess: for if the strongest man in the country take it above four or five times in twentyfour hours, he is sure to fall into a lethargy...that sleep, as sweet as it seems to be, carries him insensibly to his grave. (Gervaise 1971, p. 23; cf. Hodgson 1999, p. 32)

Gervaise was describing what was known as 'madak', a mixture of shredded tobacco and semi-refined opium with which the Chinese (in China) were experimenting (Zheng 2003, pp. 10-11, 14). It had evidently found its way to Makassar. ${ }^{15}$ Chinese opium smoking developed as an offshoot of tobacco smoking; madak was an interim development until around 1760, when it was discovered how to prepare opium for smoking without tobacco. This brought about the development of the distinctive metal bowl at the distal end of an opium pipe: the opium in fact vaporises (it does not burn) when heated (Courtright 2001 p. 33). Is it possible that the practice of mixing tobacco and opium and smoking madak was witnessed and tried by Aboriginal people, in Makassar perhaps, and that this triggered the idea of using the pipes for tobacco alone?

In other, mostly inland regions of the Northern Territory, the long pipe was adopted directly from Chinese opium users and modified for use as a tobacco pipe. Thousands of Chinese labourers were brought into the Northern Territory from the 1870s to work in mining enterprises in the Top End, which they soon

15 In the late eighteenth century, the natives of Batavia were also said to be 'very fond' of opium, which they smoked 'together with their tobacco' (Zheng 2003, p. 10). 
came to dominate. By 1888 the Chinese population peaked in the Territory at more than 6000, outnumbering Europeans (Ganter 2003). Aboriginal people from the Alligator rivers region, Adelaide River, Roper and Daly rivers regions made wet season migrations into the many small mining settlements where they mixed with Chinese workers and, by the early twentieth century, the extent of fraternisation between Aboriginal people and the Chinese had precipitated sensational press reports of Aboriginal opium smoking. The South Australian newspaper The Observer reported on 20 August 1904 that 60 per cent of the Chinese were opium smokers, and that

[i]n spite of every precaution and vigilance on the part of the police, the blacks succeed in getting it from the Chinese, and frequently rough-made opium pipes, manufactured from reeds and glass bottles and bamboos, which blacks have used, are found. Formerly the blacks smoked in Chinese quarters and used Chinese pipes, but the visits of police have led them to construct their own pipes and to take opium into the bush, where they smoke it.

Frank Gillen saw Aboriginal people using what he referred to as 'Chinese' pipes for tobacco. During his 1901-02 expedition across the centre to the Gulf of Carpentaria with Baldwin Spencer, Gillen noted in his journal the adaptations Aboriginal people were making to their material culture using introduced objects. Heading east from Powell's Creek, Spencer and Gillen encountered two men holding crocodile spears they had adapted by adding prongs made from iron nails and the blade of a butcher's knife. 'Another of their adaptations', Gillen wrote,

is the Chinese pipe which is modelled on the pipe used for smoking opium by the Chinese. We saw these pipes first at Powells Creek [past Renner Springs, well inland] and since then there has been one or more in every camp visited. In some cases the stem of the pipe is of bamboo in which case it must have been traded through from the coast but in most cases it is of hollow wood one end being stuffed up and a piece of tin inserted an inch or two back to hold the tobacco... The idea of smoking tobacco in this way must have originated with the coastal blacks who have come in contact with the Chinese and the custom is gradually spreading inland. (Gillen 1968, p. 298) 


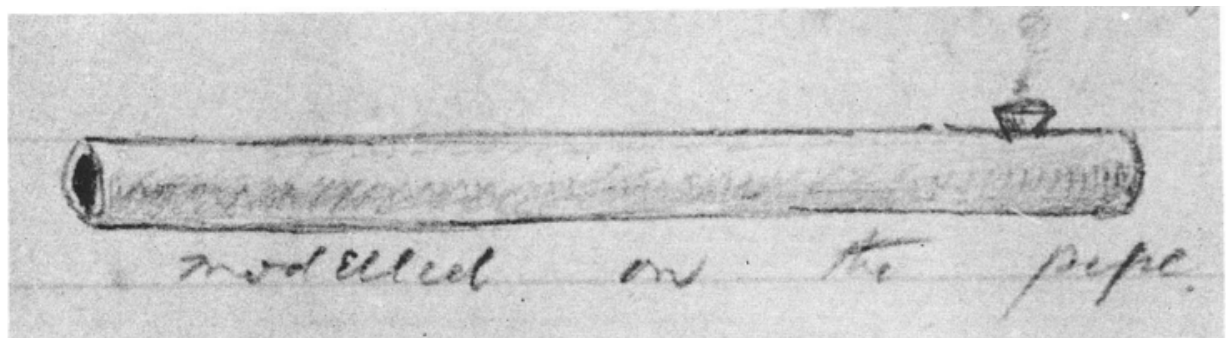

Figure $9.6^{\prime}$ '...the Chinese pipe which is modelled on the pipe used for smoking opium...'

Source: Drawing in Gillen's diary (1968, p. 298)

In November at Borroloola, Gillen noted that many Aborigines had pipes fashioned 'like the Chinese opium pipes and made out of bamboo' (Gillen 1968, p. 316). He mentions that at Borroloola there was both a Chinese gardener and a Chinese garden; but it is peculiar that Gillen does not associate the pipe with the Macassans: he was well aware of the 'Malay traders' and commented that some Borroloola men ‘talk Malay' (Gillen 1968, p. 317).

\section{Conclusion}

The style and uses of the long smoking pipe have undergone numerous historical, cultural and social transformations, with the Chinese originally smoking tobacco alone in long-stemmed pipes, then adding tobacco to opium - a practice that spread to Southeast Asia. The invention of the closed-bowl opium pipe later allowed raw opium alone to be 'cooked' or vaporised. This was the pipe that, with a minor alteration to the bowl, reappeared as the 'Macassan' pipe in Australia, adapted by coastal Aboriginal people to the smoking of tobacco. Gillen confidently assumed that Aborigines had adapted the pipe directly from the Chinese. It is notable that Macknight, Warner and Thomson all chose their words carefully when discussing the origins of this pipe. Macknight, for example, said that it was 'possibly' borrowed from the Macassans and that it derived from a type of pipe used mainly for smoking opium (Macknight 1976, p. 91). I believe it was wise to be so cautious: after all, while there is no doubt that Aboriginal people tasted and enjoyed Macassan arrack, there remains considerable doubt about the process whereby the opium pipe metamorphosed into an Aboriginal tobacco pipe. Mysteriously, the Macassans who supposedly introduced pipe smoking were a people who did not usually smoke, but instead were chewers of betel and tobacco - methods of ingestion that northern Aborigines never adopted. 


\section{References}

Achadi, A., S. Widyastuti and S. Barber (2005) 'The relevance and prospects of advancing tobacco control in Indonesia', Health Policy, 72, pp. 333-49.

Atlas (1885) Ethnographische atlas, bevattende afbeeldingen van voorwerpen uit het leven en de huishouding der Makassaren, 's Gravenhage: Nijhoff.

Beaglehole, J. C. (ed.) (1963) The Endeavour Journal of Joseph Banks, 1768-1771. Volume II, Sydney: Trustees of the Public Library of New South Wales \& Angus \& Robertson.

Berndt, R. M. and C. H. Berndt (1954) Arnhem Land: Its history and its people, Melbourne: F. W. Cheshire.

Brady, M. (2008) First Taste. How Indigenous Australians learned about grog, Canberra: Alcohol Education and Rehabilitation Foundation.

Brady, M. and V. McGrath (2010) 'Making Tuba in the Torres Strait Islands: the cultural diffusion and geographic mobility of an alcoholic drink', Journal of Pacific History, 45 (3), pp. 108-22.

Burkhill, I. H. (1966) A Dictionary of the Economic Products of the Malay Peninsula, Kuala Lumpur: Ministry of Agriculture and Co-operatives.

Burningham, N. (1994) 'Aboriginal nautical art: a record of the Macassans and the pearling industry in northern Australia', The Great Circle: Journal of the Australian Association for Maritime History, 16 (2), pp. 139-51.

Cameron, J. M. R. (ed.) (1999) Letters from Port Essington, 1838-1845, Darwin: Historical Society of the Northern Territory.

Cawte, J. (1985) 'Psychoactive substances of the South Seas: betel, kava and pituri', Australian and New Zealand Journal of Psychiatry, 19, pp. 83-7.

Cooke, M. (1987) Makassar and Northeast Arnhem Land: Missing links and living bridges, Batchelor, NT: Educational Media Unit, Batchelor College.

Courtwright, D. T. (2001) Forces of Habit: Drugs and the making of the modern world, Cambridge, Mass.: Harvard University Press.

Earl, G. W. (1882) Handbook for Colonists in Tropical Australia, London: George Rivers.

Evans, N. (1992) 'Macassan loanwords in Top End languages', Australian Journal of Linguistics, 12, pp. 45-91. 
Evans, N. (1997) 'Macassan loans and linguistic stratification in western Arnhem Land', in P. McConvell and N. Evans (eds), Archaeology and Linguistics: Aboriginal Australia in global perspective, Melbourne: Oxford University Press, pp. 237-60.

Fox, J. J. (1977) Harvest of the Palm: Ecological change in eastern Indonesia, Cambridge, Mass.: Harvard University Press.

Ganter, R. (2003) 'Mixed relations', in P. Edwards and S. Yuanfang (eds), Lost in the Whitewash: Aboriginal-Asian encounters in Australia 1901-2001, Canberra: Humanities Research Centre, The Australian National University, pp. 69-83.

Gervaise, N. (1971 [1701]) An Historical Description of the Kingdom of Macassar in the East-Indies, Farnborough, UK: Gregg International Publishers [Originally printed in London by Tho. Leigh \& D. Midwinter].

Gillen, F. J. (1968) Gillen's Diary. The camp jottings of F. J. Gillen on the Spencer and Gillen expedition across Australia 1901-1902, Adelaide: Libraries Board of South Australia.

Goodman, J. (1993) Tobacco in History: The cultures of dependence, London \& New York: Routledge.

Hodgson, B. (1999) Opium. A portrait of the heavenly demon, San Francisco: Chronicle Books.

Hordern, M. (2002) King of the Australian Coast: The work of Phillip Parker King in the Mermaid and the Bathurst 1817-1822, Melbourne: Melbourne University Press.

Knaap, G. and H. Sutherland (2004) Monsoon Traders: Ships, skippers and commodities in eighteenth century Makassar, Leiden: KITLV Press.

Macknight, C. C. (1976) The Voyage to Marege': Macassan trepangers in northern Australia, Carlton, Vic.: Melbourne University Press.

Macknight, C. C. and A. G. Thorne (1968) 'Two Macassan burials in Arnhem Land', Archaeology \& Physical Anthropology in Oceania, III (3), pp. 216-22.

MacPherson, J. (1921) 'The use of narcotics and intoxicants by the native tribes of Australia, New Guinea, and the Pacific', Sydney University Medical Journal, (May), pp. 108-22.

Mulvaney, J. (1988) 'Aboriginal Australians abroad 1606-1875', Aboriginal History, 12 (1), pp. 41-7. 
Mulvaney, J. and N. Green (1992) Commandant of Solitude: The journals of Captain Collet Barker 1828-1831, Melbourne: Miegunyah Press.

Reid, A. (1985) 'From betel-chewing to tobacco-smoking in Indonesia', The Journal of Asian Studies, 44 (3), pp. 529-47.

Rooney, D. F. (1993) Betel Chewing Traditions in South-East Asia, Kuala Lumpur: Oxford University Press.

Rosenman, H. (ed.) (1992) Two Voyages to the South Seas. Capt. Jules S. C. Dumont $D^{\prime}$ Urville, Melbourne: Melbourne University Press.

Searcy, A. (1984 [1909]) In Australian Tropics, (Facsimile edn), Perth: Hesperian Press.

Strickland, S. S. (2002) 'Anthropological perspectives on use of the areca nut', Addiction Biology, 7, pp. 85-97.

Thomson, D. F. (1939) 'Notes on the smoking-pipes of north Queensland and the Northern Territory of Australia', Man, 39 (June), pp. 81-91.

Thomson, D. F. (1949) Economic Structure and the Ceremonial Exchange Cycle in Arnhem Land, Melbourne: Macmillan \& Co.

Walker, A. and R. D. Zorc (1981) 'Austronesian loanwords in Yolngu-Matha of northeast Arnhem Land', Aboriginal History, 5 (2), pp. 109-34.

Wallace, A. R. (1989 [1869]) The Malay Archipelago, Oxford: Oxford University Press.

Warner, W. L. (1958) A Black Civilization: A social study of an Australian tribe, (Revised edn), New York: Harper \& Brothers.

Webling, A. C. (1995) The Journals of Alfred Charles Webling, Western Creek, ACT: Genie Publishing.

Zheng, Y. (2003) 'The social life of opium in China, 1483-1999', Modern Asian Studies, 37 (1), pp. 1-39.

Zorc, R. D. (1986) Yolngu-Matha Dictionary, Batchelor, NT: School of Australian Linguistics. 